\title{
Central Pulse Pressure and Variability in Matrix Metalloproteinases Genes and Their Inhibitors in Patients With Ischemic Heart Disease
}

\author{
A. VAŠKŮ ${ }^{1}$, J. BIENERTOVÁ-VAŠKŮ ${ }^{1}$, J. PAŘENICA ${ }^{2}$, M. PÁVKOVÁ GOLDBERGOVÁ ${ }^{1}$, \\ J. NOVÁK ${ }^{1}$, M. CHMELÍKOVÁ ${ }^{1}$, D. HONSOVÁ ${ }^{1}$, J. LIPKOVA ${ }^{1}$, P. KALA $^{2}$, J. SPINAR \\ ${ }^{1}$ Department of Pathological Physiology, Faculty of Medicine, Masaryk University, Brno, Czech \\ Republic, ${ }^{2}$ Department of Internal Cardiology Medicine, Faculty of Medicine, Masaryk University, \\ University Hospital Brno, Brno, Czech Republic
}

Received March 16, 2014

Accepted July 31, 2014

\section{Summary}

Matrix metalloproteinases (MMPs) as well as their inhibitors (TIMPs) play a crucial role in controlling extracellular matrix turnover and have recently been associated with atherosclerosis, myocardial and vascular injury. Moreover, the genetic variability of MMP genes has been suggested to play an important role in vascular remodeling and age-related arterial stiffening. This study aims to describe associations of 14 selected polymorphisms in genes for MMPs and TIMPs with selected cardiovascular parameters (including central pulse pressure), clinical conditions and drug treatment profiles in 411 stable ischemic patients with preserved systolic function of the left ventricle. The genotyping of 14 single-nucleotide polymorphisms in 8 genes was carried out either using $5^{\prime}$ exonuclease (TaqMan $囚$ ) reagents or by restriction analysis. Numerous associations of the investigated polymorphisms with systolic and diastolic blood pressure, maximum left ventricular end diastolic pressure and ejection fraction were observed. While some of the observed effects were found to be age-dependent, associations with clinical conditions (hypertension, diabetes mellitus, angina pectoris) were only observed in women and associations with four groups of drugs (statins, nitrates, calcium channel blockers, anti-aggregation drugs) were only observed in men. The results of this study indicate that the genetic variability of MMPs and TIMPs is an important factor which influences cardiovascular functions and may have important consequences for individual therapy customization in the future.

\section{Key words}

Central pulse pressure $\bullet$ Matrix metalloproteinase $\bullet$ MMP • TIMP - SNP

\section{Corresponding author}

A. Vašků, Department of Pathological Physiology, Faculty of Medicine, Masaryk University, Kamenice 5, 62500 Brno, Czech Republic. Fax: +420 54949 4340. E-mail: avasku@med.muni.cz

\section{Introduction}

It is well known that central systolic and pulse pressure (PP) are correlated with the severity of coronary atherosclerosis, thickened media and intima in carotid arteries and left ventricular hypertrophy and diastolic dysfunction (Jankowski et al. 2004, Ostergren et al. 2008, Roman et al. 2010). This correlation is referred to as being closer in the case of central than in the case of peripheral blood pressure (Williams et al. 2006, Roman et al. 2007, Roman et al. 2010). The correlation between PP and coronary atherosclerosis is especially significant as most deaths resulting from cardiovascular disease are caused by coronary artery events (Palatini et al. 2011). It has also been reported that central PP is physiologically higher in men compared to women and increases with age (Safar and Jankowski 2009).

Blood vessels are constantly adjusting to neuronal, hormonal and hemodynamic stimuli. While short-term alterations in vascular tone occur as a result of changes in endothelial cell function, increased neuroendocrine drive or altered vascular smooth muscle (VSM) sensitivity, chronic changes in vascular function often include structural changes in blood vessel architecture. Vascular remodeling involves lasting structural changes in the vessel wall occurring in response to hemodynamic stimuli. Persistent changes in 
the composition and/or size of bloods vessel associated with vascular remodeling are believed to facilitate adaptation and repair (Raffetto and Khalil 2008). Blood vessel remodeling dependent on blood flow was previously confirmed as a key factor in physiological processes including angiogenesis during development, wound healing and physical training as well as the onset and development of pathological states like hypertension, ischemic heart disease and tumor growth (Dumont et al. 2007).

Central aortic pressures and hemodynamics may play a critical role in the diagnostics of various pathological conditions. It has been reported that central aortic PP may be a determinant of clinical outcomes and differences in central aortic pressures may be potentially used to explain the different clinical outcomes of therapy (Williams et al. 2006). These findings have been discussed in several studies (Ostergren et al. 2008, O'Rourke et al. 2010) and refuted by others (Dart et al. 2006, Mitchell et al. 2010).

The extracellular matrix (ECM) of the vessel wall is composed of collagen, elastin, glycoproteins and proteoglycans. The turnover of collagen and elastin (i.e. proteins closely associated with structural strength and elasticity) is regulated by matrix metalloproteinases (MMPs), a family of proteolytic enzymes which degrade various components of the ECM. The MMP family includes collagenases, gelatinases, stromelysins, matrilysins and membrane-type MMPs (Back et al. 2010). MMPs degrade the ECM by affecting the production of weaker collagen and frayed elastin fibers. When the vessel wall is exposed to immunological stress, inflammatory cells such as polymorphonuclear neutrophils (PMNs) and macrophages produce a variety of MMPs (MMP1, 7, 8, 13) as well as elastase; these enzymes are subsequently responsible for the deleterious changes outlined above. Their activity is regulated by enhanced gene expression, followed by post-translational activation of pro-MMP cleavage and by numerous interactions between MMPs, plasmin, thrombin and reactive oxygen species (ROS) which are not yet fully understood. The activation of MMPs during the acute phase following tissue injury is crucial for immune cells, which play a role in preserving tissue function; however, the chronic activation of MMPs is believed to be deleterious, resulting in adverse events such as the previously mentioned vascular remodeling, atherosclerosis and myocardial dysfunction (Klein and Bischoff 2011).
Tissue inhibitors of MMPs (TIMPs) counteract the abovementioned processes, providing a regulatory mechanism and maintaining balance between the synthesis and degradation of ECM (Shirwany and Zou 2010). TIMPs are specific endogenous inhibitors which bind to MMPs in a 1 to 1 ratio. Four types of TIMPs (TIMP1, 2, 3, and 4) have been identified in vertebrates. Their expression is regulated during tissue development and remodeling (Brew et al. 2000).

Endogenous TIMPs reduce excessive proteolytic ECM degradation caused by MMPs. An imbalance in the MMPs/TIMPs activity ratio may constitute an underlying factor in the pathogenesis of vascular diseases such as abdominal aortic aneurysm, varicose veins, hypertension and coronary artery disease (Raffetto and Khalil 2008). The biochemical structure and function of MMPs has been the subject of several reviews and articles (Liu et al. 1997, Galis and Khatri 2002, Visse and Nagase 2003). Metalloelastase (MMP12) is expressed especially in macrophages and is substantial for their migration (Shapiro et al. 1993). However, very little is known about the possible effect of the genetic variability of genes associated with MMP signaling on central pulse pressure, especially in specific patient populations.

This study thus aims to (i) investigate associations between selected polymorphisms in genes for MMPs and their inhibitors and cardiovascular parameters such as central pulse pressure and other hemodynamic characteristics and to (ii) investigate the possible association of these polymorphisms with the clinical conditions and drug treatment profiles of stable ischemic patients with preserved systolic functioning of the left ventricle in a genotype-phenotype study.

\section{Material and Methods}

\section{Study population}

During the course of a period from May 2009 to May 2011, a total of 537 patients were recruited for a study of the effects of MMP gene polymorphisms on aortic PP. All patients were referred to the catheter laboratory of the Cardiology Department of the University Hospital Brno for diagnostic coronary angiography. Patients with acute MI, aortic valve disease (i.e. aortic stenosis with a peak-to-peak gradient $>25 \mathrm{~mm} \mathrm{Hg}$ and aortic regurgitation greater than grade 1), mitral valve disease or ejection fraction (EF) $<50 \%$, were excluded from the study. A total of 411 patients were subsequently used for the purposes of this case-case 
study. The recruitment of healthy individuals for the purposes of explorative coronarography was rejected by the local Ethics Committee.

Informed written consent was obtained from all subjects prior to their participation in the trial. The study protocol complied with the Declaration of Helsinki and was approved by the local Ethics Committee.

\section{Definitions and study protocol}

Baseline characteristics (past medical history, current symptoms and risk factors) and medication were obtained prior to the examination. The presence of diabetes mellitus was defined as fasting blood glucose of $\geq 7 \mathrm{mmol} / \mathrm{l}$ or the usage of an antidiabetic drug or insulin. Hypercholesterolemia was defined as total plasma cholesterol $\geq 5 \mathrm{mmol} / 1$ or low-density lipoprotein (LDL) cholesterol $\geq 2.6 \mathrm{mmol} / 1$ or an existing lipid-lowering drug prescription. Ischemic heart disease was defined as a $\geq 50 \%$ reduction of the intraluminal diameter of any of the coronary arteries (left main, left anterior descending, left circumflex or right coronary artery) or the main branches with a diameter of $\geq 2.0 \mathrm{~mm}$.

\section{Clinical laboratory methods}

Invasive intra-aortic systolic (SBP) and diastolic blood pressure (DBP) were measured using a fluid-filled catheter (4Fr pigtail catheter) in the ascending aorta; left ventricular end-diastolic pressure (LVEDP) was measured in the left ventricle with the patient in a supine position. Aortic pulse pressure (PP) was calculated as the difference between aortic SBP and aortic DBP; mean arterial pressure (MAP) was calculated as follows: $\mathrm{MAP}=\mathrm{DBP}+(\mathrm{SBP}-\mathrm{DBP}) / 3$. Heart rate was recorded using standard electrocardiography monitoring.

\section{Genotyping}

DNA for analysis was extracted from $5 \mathrm{ml}$ of peripheral blood collected from each patient following a three-hour fasting period; DNA was subsequently extracted from peripheral leukocytes using the standard proteinase $\mathrm{K}$ technique.

The genotyping of 14 single-nucleotide polymorphisms (SNPs) in 8 selected genes (Table 1) was carried out using either $5^{\prime}$ exonuclease (TaqMan ${ }^{\circledR}$ ) reagents on the ABI Prism ${ }^{\circledR} 7000$ system (Applied Biosystems, Foster City, CA, USA) or by restriction analysis (used restriction enzymes are listed in Table 1; detailed protocols are available upon request). Assays were validated by double genotyping of $10 \%$ of the samples and direct sequencing using Big Dye v 1.1 terminator reagents (Applied Biosystems).

Table 1. Examined polymorphisms - methods.

\begin{tabular}{|c|c|c|c|c|}
\hline Gene & Chromosome & SNP & Type & Method \\
\hline \multirow{5}{*}{$M M P 2$} & \multirow{5}{*}{$16 \mathrm{q} 13$} & rs $2285053 /-735 \mathrm{C} / \mathrm{T}$ & $\mathrm{P}$ & $\operatorname{HinfI} / 37^{\circ} \mathrm{C}$ \\
\hline & & rs $243865 /-1306 \mathrm{C} / \mathrm{T}$ & $\mathrm{P}$ & $\mathrm{XspI} / 37^{\circ} \mathrm{C}$ \\
\hline & & rs7201 & 3' UTR & TaqMan SNP genotyping \\
\hline & & rs243866/-1575G/A & $\mathrm{P}$ & TaqMan SNP genotyping \\
\hline & & rs243864/-790G/T & $\mathrm{P}$ & TaqMan SNP genotyping \\
\hline$M M P 3$ & $11 \mathrm{q} 23$ & rs3025058/-1171 5A/6A & $\mathrm{P}$ & $\mathrm{XmnI} / 37^{\circ} \mathrm{C}$ \\
\hline$M M P 7$ & $11 q 21-q 22$ & rs11568819/-202C/T & $\mathrm{P}$ & TaqMan SNP genotyping \\
\hline \multirow{2}{*}{$M M P 8$} & \multirow{2}{*}{$11 \mathrm{q} 21-\mathrm{q} 22$} & rs $11225395 /-799 \mathrm{C} / \mathrm{T}$ & $\mathrm{P}$ & $\mathrm{SfcI} / 37^{\circ} \mathrm{C}$ \\
\hline & & $\mathrm{rs} 2155052 /+17 \mathrm{C} / \mathrm{G}$ & 5' UTR & $\operatorname{DdeI} / 37^{\circ} \mathrm{C}$ \\
\hline \multirow{2}{*}{$M M P 12$} & \multirow{2}{*}{$11 \mathrm{q} 22.2-\mathrm{q} 22.3$} & rs7123600 & I & TaqMan SNP genotyping \\
\hline & & rs2276109/-124A/G & $\mathrm{P}$ & TaqMan SNP genotyping \\
\hline TIMP1 & $\mathrm{Xp11.3-p11.23}$ & rs4898 & I & TaqMan SNP genotyping \\
\hline$T I M P 2$ & $17 q 25$ & rs8176329 & $\mathrm{I}$ & TaqMan SNP genotyping \\
\hline TIMP3 & $22 q 12.1-q 13.2$ & rs1065314 & 3' UTR & TaqMan SNP genotyping \\
\hline
\end{tabular}

$\mathrm{P}=$ promoter, $\mathrm{E}=$ exon, $\mathrm{I}=$ intron, $3^{\prime} \mathrm{UTR}=3$ untranslated region, $5^{\prime}$ UTR $=5^{\prime}$ untranslated region 


\section{Data analysis and statistics}

Data were reported as median, range (for continuous variables) and percentage proportion (for discrete variables). In order to analyze differences between individual groups, $t$-tests and analysis of variance (ANOVA) tests were used for continuous normally distributed variables and the Mann-Whitney $U$ test and Kruskal-Wallis ANOVA tests were used for continuous non-normally distributed variables.

\section{Results}

Significant differences in clinical parameters between males and females were observed with respect to smoking prevalence, occurrence of stenosis of multiple coronary arteries, stenosis of single coronary artery and trunk stenosis. On the whole, the significance of clinical parameters was found to be higher in the case of male patients (Table 2).

Some differences between males and females were also observed with respect to the prescription of individual drug groups: while angiotensin-converting enzyme inhibitors (ACEI) were prescribed to men more frequently, angiotensin receptor type 1 (AT1R) blockers and diuretics were prescribed to women more often (Table 3).

Table 2. Clinical characteristics.

\begin{tabular}{|c|c|c|c|}
\hline & $\begin{array}{l}\text { N-women } \\
(\mathrm{N}=\mathbf{1 8 0})\end{array}$ & $\begin{array}{l}\text { N-men } \\
(\mathrm{N}=\mathbf{2 3 1})\end{array}$ & p-value \\
\hline Hypertension & $78 \%$ & $75 \%$ & 0.194 \\
\hline Diabetes mellitus & $21 \%$ & $22 \%$ & 0.358 \\
\hline Hyperlipoproteinemia & $83 \%$ & $82 \%$ & 0.415 \\
\hline Positive personal history of myocardial infarction & $8 \%$ & $16 \%$ & 0.03 \\
\hline Smoking & $17 \%$ & $37 \%$ & 0.00 \\
\hline Angina pectoris & $59 \%$ & $66 \%$ & 0.04 \\
\hline Stenosis of coronary artery & $36 \%$ & $56 \%$ & 0.00 \\
\hline Stenosis of trunk & $3 \%$ & $11 \%$ & 0.0001 \\
\hline Stenosis of RIA & $27 \%$ & $41 \%$ & 0.0002 \\
\hline Stenosis of $R C$ & $15 \%$ & $28 \%$ & 0.00006 \\
\hline Stenosis of $A C D$ & $15 \%$ & $32 \%$ & 0.000001 \\
\hline
\end{tabular}

$\mathrm{RIA}=$ ramus interventricularis ant. art. cor. dextrae, $\mathrm{RC}=$ ramus circumflexus art. cor. sinistrae, $\mathrm{ACD}=$ arteria coronaria dextra

Table 3. Therapy.

\begin{tabular}{llll}
\hline & $\begin{array}{l}\text { N-women } \\
\mathbf{N = 1 8 0 )}\end{array}$ & $\begin{array}{l}\text { N-men } \\
(\mathbf{N}=\mathbf{2 3 1})\end{array}$ & p-value \\
\hline Anti-aggregation & $78 \%$ & $75 \%$ & 0.194 \\
Beta blockers & $59 \%$ & $59 \%$ & 0.523 \\
Inhibitors of ACE & $\mathbf{4 0 \%}$ & $\mathbf{5 3} \%$ & $\mathbf{0 . 0 0 1}$ \\
Inhibitors of AT1R & $\mathbf{2 2 \%}$ & $\mathbf{1 1} \%$ & $\mathbf{0 . 0 0 0 4}$ \\
Ca-blockers & $29 \%$ & $26 \%$ & 0.262 \\
Diuretics & $\mathbf{3 0} \%$ & $\mathbf{2 2} \%$ & 0.02 \\
Statins & $57 \%$ & $54 \%$ & 0.475 \\
Peroral antidiabetics & PADs) & $12 \%$ & 0.446 \\
Insulin & $12 \%$ & $3 \%$ & 0.455 \\
Nitrates & $3 \%$ & $4 \%$ & 0.279 \\
Fibrates & $5 \%$ & $27 \%$ & 0.274 \\
\hline
\end{tabular}


Significant differences in systolic blood pressure in the aorta $(\mathrm{p}=0.01)$, pulse pressure in the aorta $(p=0.0001)$ and LVEDP $\max (p=0.02)$ were observed between men and women of similar ages. Similar differences were not established in case of peripheral blood pressure values (data not shown).

As significant gender-specific differences in central pulse pressure were observed, further statistical analyses were performed separately for each sex. Several significant genotype-phenotype associations of different polymorphisms in MMPs and their inhibitors were subsequently established (Tables 4 and 5).

In women, the most frequent associations included polymorphisms in the MMP2 gene, associated with DBP_arm (AA carriers in MMP-rs243866 presented with the lowest values of DBP_arm) and moderate (GT carriers in MMP2-rs243864-790 suffer 3 times more frequently from moderate stages of angina pectoris) to severe (CC carriers in MMP2-rs2285053 have a 14.88 times higher risk of severe angina pectoris occurrence) angina pectoris occurrence.

In men, MMP12 gene polymorphisms were most frequently associated, especially with SBP_arm (TT carriers in MMP12-rs2276109 presented with the highest values of SBP_arm) and DBP_arm (either GG or AA homozygotes in MMP12-rs7123600 presented with higher values of DBP_arm compared to heterozygotes).

Table 4. Significant genotype-phenotype associations in women.

\begin{tabular}{|c|c|c|}
\hline Polymorphism & Phenotype & Result \\
\hline MMP8 rs11225395 & Age & $\begin{array}{l}\text { Carriers of the } \mathrm{CC} \text { genotype comprised the significantly } \\
\text { oldest group (median }=66 \text {, range } 55-81 \text { years; } \mathrm{p}=0.02 \text { ) }\end{array}$ \\
\hline MMP7 rs11568819 & LVEDP $_{\max }$ & $\begin{array}{l}\text { The GG genotype polymorphism MMP7 rs } 11568819 \text { has a } \\
\text { higher level of LVEDP_max (median=14, range 4-33) in } \\
\text { comparison with the AG genotype (median=10, range 6- } \\
\text { 18); } \mathrm{p}=0.03\end{array}$ \\
\hline TIMP2 rs8176329 & $\mathrm{EF}_{\text {angio }}$ & $\begin{array}{l}\text { The GG genotype (median=67, range 56-84) has the } \\
\text { highest value of EF_angio in comparison with AG } \\
\text { (median }=60 \text {, range } 56-84 \text { ) and AA (median }=60 \text {, range } 45- \\
79) ; p=0.05\end{array}$ \\
\hline$M M P 2 \quad r s 243866$ & DBP_arm & $\begin{array}{l}\text { Carriers of the AA genotype have the lowest value of } \\
\text { diastolic blood pressure measured on the arm (median=80, } \\
\text { range 70-90) in comparison with women with the following } \\
\text { genotypes: AG (median=90, range } 75-115) \text {, GG } \\
\text { (median=90, range } 60-115) ; \mathrm{p}=0.005\end{array}$ \\
\hline$M M P 12$ rs 7123600 & Hypertension & $\begin{array}{l}\text { AA and GG genotypes are at an almost } 5 \text { times higher risk } \\
\text { of hypertension in comparison with the } A G \text { genotype } \\
\left(\mathrm{OR}=4.82(1.89-12.30) ; \mathrm{p}=0.001, \mathrm{p}_{\text {corr }}=0.003\right)\end{array}$ \\
\hline TIMP2 rs8176329 & Diabetes mellitus & $\begin{array}{l}\text { Carriers of the AA genotype are at a } 4 \text { times higher risk of } \\
D M \text { in comparison with carriers of the } A G \text { and } G G \\
\text { genotypes }\left(O R=4.14(0.94-18.34) ; p=0.005, p_{\text {corr }}=0.02\right)\end{array}$ \\
\hline$M M P 2$ rs 2285053 & $\begin{array}{l}\text { Severe stage of angina } \\
\text { pectoris (AP_CCS3) }\end{array}$ & $\begin{array}{l}\text { The } C C \text { genotype is associated with a } 14.88 \text { times higher } \\
\text { risk of severe angina pectoris in comparison with the } \\
\text { remaining genotypes }(\mathrm{OR}=14.88(1.56-142.20) ; \mathrm{p}=0.009 \text {, } \\
\left.\mathrm{p}_{\text {corr }}=0.03\right)\end{array}$ \\
\hline MMP2 rs243864-790 & $\begin{array}{l}\text { Moderate stage of } \\
\text { angina pectoris } \\
\left(\mathrm{AP} \_\mathrm{CCS} 2\right)\end{array}$ & $\begin{array}{l}\text { Carriers of the GT genotype suffer } 3 \text { times more frequently } \\
\text { from the moderate stage of angina pectoris }(\mathrm{OR}=3.38 \\
\left.(1.55-7.36) ; \mathrm{p}=0.0016, \mathrm{p}_{\text {corr }}=0.005\right)\end{array}$ \\
\hline TIMP2 rs8176329 & $\begin{array}{l}\text { Peroral antidiabetics } \\
\text { (PADs) }\end{array}$ & $\begin{array}{l}\text { Administered } 3 \text { times more frequently to carriers of the AA } \\
\text { genotype }\left(O R=3.22(1.15-9.00) ; p=0.015, p_{\text {corr }}=0.04\right)\end{array}$ \\
\hline
\end{tabular}


Examined polymorphisms in MMPs and TIMPs were also associated with maximum left ventricular enddiastolic pressure (LVDEP ${ }_{\max }$ ) (GG genotype in MMP7rs11568819 exhibited higher LVDEP $_{\max }$ in comparison with other genotypes) and ejection fraction measured by angiography $\left(\mathrm{EF}_{\text {angio }}\right)$ (GG carriers in TIMP3-rs8176329 exhibited higher $\mathrm{EF}_{\text {angio }}$ values in comparison with other genotypes) in women; $\mathrm{LVDEP}_{\max }$ and $\mathrm{EF}_{\text {angio }}$ constitute the two most important parameters which reflect the functional properties of the heart.

Table 5. Significant genotype-phenotype associations in men.

\begin{tabular}{|c|c|c|}
\hline Polymorphism & Phenotype & Result \\
\hline MMP8 rs11225395 & Pulse pressure_aor & $\begin{array}{l}\text { Carriers of the TT genotype have the highest central pulse } \\
\text { pressure }(p=0.01)\end{array}$ \\
\hline MMP12 rs2276109 & SBP_arm & $\begin{array}{l}\text { Carriers of the TT genotype have the highest value of SBP } \\
\text { pressure }(p=0.01)\end{array}$ \\
\hline$M M P 12$ rs 7123600 & DBP_arm & $\begin{array}{l}\text { Carriers of both homozygotes ( } \mathrm{GG} \text { and AA) have the highest } \\
\text { value of DBP pressure }(\mathrm{p}=0.009)\end{array}$ \\
\hline MMP12 rs2276109 & DBP_arm & $\begin{array}{l}\text { Carriers of the CC genotype have the highest value of DBP } \\
\text { pressure }(p=0.02)\end{array}$ \\
\hline $\begin{array}{l}\text { Promoter triple genotype } \\
(G G C C T T) \text { in } M M P 2 \text { gene }\end{array}$ & $\begin{array}{l}\text { Anti-aggregation } \\
\text { therapy }\end{array}$ & $\begin{array}{l}\text { Prescribed almost } 5 \text { times more frequently to carriers of other } \\
\text { genotypes }\end{array}$ \\
\hline$M M P 2 \quad r s 243866-1575$ & Ca blockers & $\begin{array}{l}\text { Administered twice as frequently to } \mathrm{AG} \text { and } \mathrm{AA} \text { patients in } \\
\text { comparison with } \mathrm{GG} \text { carriers (co-dominant model of heredity, } \\
\mathrm{OR}=2.45\left(1.34-4.47, \mathrm{p}_{\text {corr }}=0.008 \text {, sensitivity } 0.6 \text {, specificity }\right. \\
0.8 \text {, power test } 0.8)\end{array}$ \\
\hline$M M P 8 \quad r s 2155052$ & Statins & $\begin{array}{l}\text { Administered } 2.5 \text { times more frequently to } \mathrm{CG} \text { carriers in } \\
\text { comparison with } \mathrm{CC} \text { carriers } \mathrm{OR}=2.62(1.02-6.73) ; \mathrm{p}=0.03\end{array}$ \\
\hline TIMP1 rs4898 & Nitrates & $\begin{array}{l}\text { Patients with the T0 genotype were treated } 3 \text { times more } \\
\text { frequently with nitrates in comparison with the } C 0 \text { genotype } \\
(\mathrm{OR}=3.30(1.39-7.85) ; \mathrm{p}=0.005)\end{array}$ \\
\hline
\end{tabular}

Four additional polymorphisms were found to be associated with central as well as peripheral blood pressure parameters in men (see Table 5). While in women these polymorphisms were associated with clinical conditions (hypertension, diabetes mellitus, angina pectoris), no such associations were observed in men. With respect to pharmacogenetics, four groups of drugs were found to be associated with genotypes in MMPs and their inhibitors in men (statins, nitrates, calcium channel blockers and anti-aggregation drugs; see Table 5), while only one drug group (PADs; see Table 4) was associated with variability in these genes in women. No difference in the dosage of these drugs between men and women was established (Table 3).

\section{Discussion}

MMPs are proteinases which participate in the degradation and remodeling of ECM. From a physiological point of view, the activities of MMPs are thought to be precisely regulated, both at the level of transcription and activation of the pro-MMP precursor zymogens, and with respect to inhibition by endogenous inhibitors (TIMPs). Alterations in the regulation of MMP activity are believed to be involved in the pathogenesis of numerous diseases such as atherosclerosis, various types of cancer, fibrosis and other diseases. Key pathological effects of MMPs and TIMPs in cardiovascular diseases include vascular remodeling, atherosclerotic plaque instability and left ventricular remodeling after myocardial infarction. As excessive tissue remodeling as well as increased MMP activity have been identified during atherosclerotic lesion formation (including plaque disruption), MMPs represent an elegant target for therapeutic intervention aimed at the modification of vascular pathology by restoring the physiological balance 
between MMPs and TIMPs (Beaudeux et al. 2004, Kadoglou et al. 2005).

To the best of the authors' knowledge, no comparable association studies with invasively measured central PP have been carried out to date, although polymorphisms in genes coding various MMPs and TIMPs were separately associated with different measurements of arterial stiffness, blood pressure and other cardiovascular parameters in various populations (Benetos et al. 1996, Hanon et al. 2001, Medley et al. 2003, Chen et al. 2004, Medley et al. 2004).

A number of additional gender-specific associations were observed in this study. While it is wellknown that cardiovascular risk differs between men and women, central PP is also physiologically higher in men than in women, thereby predisposing men to more severe coronary atherosclerosis, higher carotid media and intima thickness, left ventricular hypertrophy and diastolic dysfunction (Jankowski et al. 2004, Ostergren et al. 2008, Roman et al. 2010). Differences between the sexes may be explained by means of the well-known effect of estrogen but also by the not-so-well-known effect of other hormones/enzymes encoded on the X-chromosome, e.g. alternative angiotensin converting enzyme (ACE2) (Vasku et al. 2013) or TIMP2, examined in this study. Various MMPs and TIMPs are also activated in different parts of the body and influenced by various transcription factors (Visse and Nagase 2003, Klein and Bischoff 2011), which may contribute to explaining the observed gender-related differences.

Focusing now on individual MMPs, TIMPs and their polymorphisms, from the MMP2 polymorphisms examined within this study, we would like to point out rs243866, associated with DBP values in women and with the administration of $\mathrm{Ca}$ blockers in men, and rs2285053, associated with the severity of angina pectoris in women. rs243866 has previously been associated with stroke outcome (Manso et al. 2010), indicating its possible involvement in (cerebro)vascular diseases. This polymorphism is located within the promoter region of the MMP2 gene, likely affecting insulin promoter factor 1 (IPF1) and POU domain class 5 transcription factor 1 (POU5F1) binding, with the AA genotype presenting with increased transcription of MMP2 (Manso et al. 2010). The results of this study, along with the results obtained by Manso et al., indicate that this polymorphism is involved in vessel function - regulating DBP in women, affecting the administration of $\mathrm{Ca}$ blockers (important for vasodilation) in men and cerebral vessel remodeling after a stroke, all of which may be altered by increased levels of MMP2 and increased ECM remodeling.

In the case of rs2285053, associated with angina pectoris severity in women, the rs2285053 haplotype with rs243865 associates with hypertension-induced LV remodeling (Lacchini et al. 2012). It may be hypothesized that this polymorphism, also located in the promoter region of MMP2, affects the binding of other transcription factors expressed predominantly in heart, which may in turn result in LV remodeling (Lacchini et al. 2012) and the modulation of angina pectoris severity.

Finally, MMP2 rs243865 was surprisingly not associated with any of the examined parameters, despite its previously reported associations with breast and bladder cancer susceptibility (Beeghly-Fadiel et al. 2009, Wieczorek et al. 2013) and its higher prevalence in obese children, where it also affects circulating MMP2 levels (Belo et al. 2013).

The MMP3 rs3025058 polymorphism influences MMP3 expression by means of the altered binding of transcription factors, as shown in experiments performed on cell cultures where the $5 \mathrm{~A}$ allele had a higher promoter activity (Ye et al. 1996). Homozygotes 5A/5A were found to suffer from higher arterial stiffness, while heterozygotes 5A/6A exhibited decreased stiffness (Medley et al. 2003). This association was not confirmed by this study. However, this polymorphism clearly deserves further attention since it is associated with an increased risk of coronary artery aneurysm formation in patients with Kawasaki's disease (Shimizu et al. 2010), abdominal aorta aneurysm occurrence (Morris et al. 2014, Saratzis et al. 2014) and also correlates with advanced stenosis (above 75\%) in coronary artery disease patients (Sakowicz et al. 2013). Surprisingly, even though it is associated with an increased risk of venous thromboembolism and the severity of coronary stenosis (Zee et al. 2009), it is not associated with myocardial infarction occurrence (Koch et al. 2010, Sakowicz et al. 2013), cervical artery dissection or varicose vein occurrence (Buss et al. 2009, Kurzawski et al. 2009). Further research on larger cohorts of patients as well as more in vitro/in vivo experiments should thus be performed to shed more light on the function of this polymorphism in vessel wall physiology and pathophysiology.

The MMP-7 rs11568819 polymorphism has not been previously associated with any cardiovascular event, even though its association with circulating MMP7 levels 
in patients with pulmonary fibrosis has been previously reported (Richards et al. 2012). The association of rs11568819 with LVEDP $_{\max }$ may also be the result of altered MMP7 levels.

According to preliminary results published by Djuric et al. (2011), the rs11225395 is associated with the development of carotid atherosclerosis. A significant association of this MMP8 polymorphism with aortic PP and the use of statins was observed in the male cohort in this study; both of these indicators hint at the potentially important role of rs11225395 in large vessel physiology, remodeling and potentially even atherosclerosis, especially as statins represent one of the most effective lipid-lowering drugs.

MMP-12 polymorphisms have previously been associated with coronary artery disease and aorta atherosclerosis (Ye 2006). The results of this study are coherent with existing findings, as homozygosity in rs7123600 is connected with hypertension in women and with increased DPB in men. The TT genotype in the second examined polymorphism, i.e. rs2276109, is also associated with increased SBP in men, all of which indicates a strong association of MMP12 function with blood pressure maintenance, especially in the case of DBP.

Finally, with respect to polymorphisms in TIMPs, the examined TIMP-1 polymorphism is known to alter TIMP1 circulating levels (higher in patients with the T allele) (Lorente et al. 2013) and in our previous study, higher levels of circulating TIMP1 were independently associated with lower ejection fraction and worse acute heart failure symptoms in men (Goldbergova et al. 2012). In this study, a more frequent administration of nitrates was observed in men bearing the $\mathrm{T}$ allele, which may be indicative of worse symptoms of angina pectoris and myocardial ischemia. To the best of our knowledge, TIMP2 and TIMP3 polymorphisms have not been studied to date and the newly observed associations of TIMP2 with ejection fraction in women are thus potentially very significant. Moreover, the association with both diabetes mellitus and the use of PADs (also in women) also indicates the potential involvement of TIMP2 in the pathophysiology of diabetes mellitus.

To conclude, this study reports numerous effects of genetic variability in MMP-signaling associated genes on multiple parameters of cardiovascular hemodynamics as well as distinct clinical phenotypes of stable ischemic patients with preserved systolic functioning of the left ventricle. The results of our research, focusing initially on the identification of genetic predisposition markers for high pulse pressure, may shed light onto numerous pathophysiological pathways and mechanisms involved in cardiovascular pathologies and thus contribute to our knowledge of physiological control mechanisms under pathophysiological conditions and provide a point of departure for a more detailed exploration of the genetic background of cardiovascular diseases, including their onset, development and therapy.

\section{Conflict of Interest}

There is no conflict of interest.

\section{References}

BACK M, KETELHUTH DF, AGEWALL S: Matrix metalloproteinases in atherothrombosis. Prog Cardiovasc Dis 52: 410-428, 2010.

BEAUDEUX JL, GIRAL P, BRUCKERT E, FOGLIETTI MJ, CHAPMAN MJ: Matrix metalloproteinases, inflammation and atherosclerosis: therapeutic perspectives. Clin Chem Lab Med 42: 121-131, 2004.

BEEGHLY-FADIEL A, LU W, LONG JR, SHU XO, ZHENG Y, CAI Q, GAO YT, ZHENG W: Matrix metalloproteinase-2 polymorphisms and breast cancer susceptibility. Cancer Epidemiol Biomarkers Prev 18: 1770-1776, 2009.

BELO VA, LUIZON MR, CARNEIRO PC, GOMES VA, LACCHINI R, LANNA CM, SOUZA-COSTA DC, TANUS-SANTOS JE: Effect of metabolic syndrome risk factors and MMP-2 genetic variations on circulating MMP-2 levels in childhood obesity. Mol Biol Rep 40: 2697-2704, 2013.

BENETOS A, GAUTIER S, RICARD S, TOPOUCHIAN J, ASMAR R, POIRIER O, LAROSA E, GUIZE L, SAFAR M, SOUBRIER F, CAMBIEN F: Influence of angiotensin-converting enzyme and angiotensin II type 1 receptor gene polymorphisms on aortic stiffness in normotensive and hypertensive patients. Circulation 94: 698-703, 1996. 
BREW K, DINAKARPANDIAN D, NAGASE H: Tissue inhibitors of metalloproteinases: evolution, structure and function. Biochim Biophys Acta 1477: 267-283, 2000.

BUSS A, PECH K, ROELVER S, BLOEMEKE B, KLOTZSCH C, BREUER S: Functional polymorphisms in matrix metalloproteinases $-1,-3,-9$ and -12 in relation to cervical artery dissection. BMC Neurol 9:40, 2009.

CHEN W, SRINIVASAN SR, BOND MG, TANG R, URBINA EM, LI S, BOERWINKLE E, BERENSON GS: Nitric oxide synthase gene polymorphism (G894T) influences arterial stiffness in adults: The Bogalusa Heart Study. Am J Hypertens 17: 553-559, 2004.

DART AM, GATZKA CD, KINGWELL BA, WILLSON K, CAMERON JD, LIANG YL, BERRY KL, WING LM, REID CM, RYAN P, BEILIN LJ, JENNINGS GL, JOHNSTON CI, MCNEIL JJ, MACDONALD GJ, MORGAN TO, WEST MJ: Brachial blood pressure but not carotid arterial waveforms predict cardiovascular events in elderly female hypertensives. Hypertension 47: 785-790, 2006.

DJURIC T, STANKOVIC A, KONCAR I, RADAK D, DAVIDOVIC L, ALAVANTIC D, ZIVKOVIC M: Association of MMP-8 promoter gene polymorphisms with carotid atherosclerosis: preliminary study. Atherosclerosis 219 : 673-678, 2011.

DUMONT O, LOUFRANI L, HENRION D: Key role of the NO-pathway and matrix metalloprotease-9 in high blood flow-induced remodeling of rat resistance arteries. Arterioscler Thromb Vasc Biol 27: 317-324, 2007.

GALIS ZS, KHATRI JJ: Matrix metalloproteinases in vascular remodeling and atherogenesis: the good, the bad, and the ugly. Circ Res 90: 251-262, 2002.

GOLDBERGOVA MP, PARENICA J, JARKOVSKY J, KALA P, POLOCZEK M, MANOUSEK J, KLUZ K, KUBKOVA L, LITTNEROVA S, TESAK M, TOMAN O, PAVEK N, CERMAKOVA Z, TOMANDL J, VASKU A, SPINAR J: The association between levels of tissue inhibitor of metalloproteinase-1 with acute heart failure and left ventricular dysfunction in patients with ST elevation myocardial infarction treated by primary percutaneous coronary intervention. Genet Test Mol Biomarkers 16: 1172-1178, 2012.

HANON O, LUONG V, MOURAD JJ, BORTOLOTTO LA, JEUNEMAITRE X, GIRERD X: Aging, carotid artery distensibility, and the Ser422Gly elastin gene polymorphism in humans. Hypertension 38: 1185-1189, 2001.

JANKOWSKI P, KAWECKA-JASZCZ K, CZARNECKA D, BRZOZOWSKA-KISZKA M, STYCZKIEWICZ K, STYCZKIEWICZ M, POSNIK-URBANSKA A, BRYNIARSKI L, DUDEK D: Ascending aortic, but not brachial blood pressure-derived indices are related to coronary atherosclerosis. Atherosclerosis 176: 151-155, 2004.

KADOGLOU NP, DASKALOPOULOU SS, PERREA D, LIAPIS CD: Matrix metalloproteinases and diabetic vascular complications. Angiology 56: 173-189, 2005.

KLEIN T, BISCHOFF R: Physiology and pathophysiology of matrix metalloproteases. Amino Acids 41: $271-290,2011$.

KOCH W, DE WAHA A, HOPPMANN P, SCHOMIG A, KASTRATI A: Haplotypes and 5A/6A polymorphism of the matrix metalloproteinase-3 gene in coronary disease: case-control study and a meta-analysis. Atherosclerosis 208: 171-176, 2010.

KURZAWSKI M, MODRZEJEWSKI A, PAWLIK A, DROZDZIK M: Polymorphism of matrix metalloproteinase genes (MMP1 and MMP3) in patients with varicose veins. Clin Exp Dermatol 34: 613-617, 2009.

LACCHINI R, JACOB-FERREIRA AL, LUIZON MR, GASPARINI S, FERREIRA-SAE MC, SCHREIBER R, NADRUZ W Jr, TANUS-SANTOS JE: Common matrix metalloproteinase 2 gene haplotypes may modulate left ventricular remodelling in hypertensive patients. J Hum Hypertens 26: 171-177, 2012.

LIU YE, WANG M, GREENE J, SU J, ULLRICH S, LI H, SHENG S, ALEXANDER P, SANG QA, SHI YE: Preparation and characterization of recombinant tissue inhibitor of metalloproteinase 4 (TIMP-4). J Biol Chem 272: 20479-20483, 1997.

LORENTE L, MARTIN M, PLASENCIA F, SOLE-VIOLAN J, BLANQUER J, LABARTA L, DIAZ C, BORREGUERO-LEON JM, JIMENEZ A, PARAMO JA, ORBE J, RODRIGUEZ JA, SALIDO E: The 372 T/C genetic polymorphism of TIMP-1 is associated with serum levels of TIMP-1 and survival in patients with severe sepsis. Crit Care 17:R94, 2013.

MANSO H, KRUG T, SOBRAL J, ALBERGARIA I, GASPAR G, FERRO JM, OLIVEIRA SA, VICENTE AM: Variants of the Matrix Metalloproteinase-2 but not the Matrix Metalloproteinase-9 genes significantly influence functional outcome after stroke. BMC Med Genet 11:40, 2010. 
MEDLEY TL, KINGWELL BA, GATZKA CD, PILLAY P, COLE TJ: Matrix metalloproteinase-3 genotype contributes to age-related aortic stiffening through modulation of gene and protein expression. Circ Res 92 : 1254-1261, 2003.

MEDLEY TL, COLE TJ, DART AM, GATZKA CD, KINGWELL BA: Matrix metalloproteinase-9 genotype influences large artery stiffness through effects on aortic gene and protein expression. Arterioscler Thromb Vasc Biol 24: 1479-1484, 2004.

MITCHELL GF, WANG N, PALMISANO JN, LARSON MG, HAMBURG NM, VITA JA, LEVY D, BENJAMIN EJ, VASAN RS: Hemodynamic correlates of blood pressure across the adult age spectrum: noninvasive evaluation in the Framingham Heart Study. Circulation 122: 1379-1386, 2010.

MORRIS DR, BIROS E, CRONIN O, KUIVANIEMI H, GOLLEDGE J: The association of genetic variants of matrix metalloproteinases with abdominal aortic aneurysm: a systematic review and meta-analysis. Heart 100: 295 $302,2014$.

O'ROURKE MF, SAFAR ME, ROMAN MJ: Letter by O'Rourke et al regarding article, "Arterial stiffness and cardiovascular events: the Framingham Heart Study". Circulation 122: e512; author reply e515, 2010.

OSTERGREN J, POULTER NR, SEVER PS, DAHLOF B, WEDEL H, BEEVERS G, CAULFIELD M, COLLINS R, KJELDSEN SE, KRISTINSSON A, MCINNES GT, MEHLSEN J, NIEMINEN M, O'BRIEN E; ASCOT INVESTIGATORS: The Anglo-Scandinavian Cardiac Outcomes Trial: blood pressure-lowering limb: effects in patients with type II diabetes. J Hypertens 26: 2103-2111, 2008.

PALATINI P, CASIGLIA E, GASOWSKI J, GLUSZEK J, JANKOWSKI P, NARKIEWICZ K, SALADINI F, STOLARZ-SKRZYPEK K, TIKHONOFF V, VAN BORTEL L, WOJCIECHOWSKA W, KAWECKAJASZCZ K: Arterial stiffness, central hemodynamics, and cardiovascular risk in hypertension. Vasc Health Risk Manag 7: 725-739, 2011.

RAFFETTO JD, KHALIL RA: Matrix metalloproteinases and their inhibitors in vascular remodeling and vascular disease. Biochem Pharmacol 75: 346-359, 2008.

RICHARDS TJ, PARK C, CHEN Y, GIBSON KF, PETER DI Y, PARDO A, WATKINS SC, CHOI AM, SELMAN M, PILEWSKI J, KAMINSKI N, ZHANG Y: Allele-specific transactivation of matrix metalloproteinase 7 by FOXA2 and correlation with plasma levels in idiopathic pulmonary fibrosis. Am J Physiol 302: L746-L754, 2012.

ROMAN MJ, DEVEREUX RB, KIZER JR, LEE ET, GALLOWAY JM, ALI T, UMANS JG, HOWARD BV: Central pressure more strongly relates to vascular disease and outcome than does brachial pressure: the Strong Heart Study. Hypertension 50: 197-203, 2007.

ROMAN MJ, OKIN PM, KIZER JR, LEE ET, HOWARD BV, DEVEREUX RB: Relations of central and brachial blood pressure to left ventricular hypertrophy and geometry: the Strong Heart Study. J Hypertens 28: 384-388, 2010.

SAFAR ME, JANKOWSKI P: Central blood pressure and hypertension: role in cardiovascular risk assessment. Clin Sci (Lond) 116: 273-282, 2009.

SAKOWICZ A, FENDLER W, LELONEK M, SAKOWICZ B, PIETRUCHA T: Genetic polymorphisms and the risk of myocardial infarction in patients under 45 years of age. Biochem Genet 51: 230-242, 2013.

SARATZIS A, BOWN MJ, WILD B, NIGHTINGALE P, SMITH J, JOHNSON C, MELAS N, KITAS GD: Association between seven single nucleotide polymorphisms involved in inflammation and proteolysis and abdominal aortic aneurysm. J Vasc Surg 2014 (in press).

SHAPIRO SD, KOBAYASHI DK, LEY TJ: Cloning and characterization of a unique elastolytic metalloproteinase produced by human alveolar macrophages. J Biol Chem 268: 23824-23829, 1993.

SHIMIZU C, MATSUBARA T, ONOUCHI Y, JAIN S, SUN S, NIEVERGELT CM, SHIKE H, BROPHY VH, TAKEGAWA T, FURUKAWA S, AKAGI T, NEWBURGER JW, BAKER AL, BURGNER D, HIBBERD ML, DAVILA S, LEVIN M, MAMTANI M, HE W, AHUJA SK, BURNS JC: Matrix metalloproteinase haplotypes associated with coronary artery aneurysm formation in patients with Kawasaki disease. J Hum Genet 55: 779-784, 2010.

SHIRWANY NA, ZOU MH: Arterial stiffness: a brief review. Acta Pharmacol Sin 31: 1267-1276, 2010. 
VASKU A, BIENERTOVA-VASKU J, PARENICA J, GOLDBERGOVA MP, LIPKOVA J, ZLAMAL F, KALA P, SPINAR J: ACE2 gene polymorphisms and invasively measured central pulse pressure in cardiac patients indicated for coronarography. J Renin Angiotensin Aldosterone Syst 14: 220-226, 2013.

VISSE R, NAGASE H: Matrix metalloproteinases and tissue inhibitors of metalloproteinases: structure, function, and biochemistry. Circ Res 92: 827-839, 2003.

WIECZOREK E, RESZKA E, JABLONOWSKI Z, JABLONSKA E, BEATA KROL M, GRZEGORCZYK A, GROMADZINSKA J, SOSNOWSKI M, WASOWICZ W: Genetic polymorphisms in matrix metalloproteinases (MMPs) and tissue inhibitors of MPs (TIMPs), and bladder cancer susceptibility. BJU Int 112: 1207-1214, 2013.

WILLIAMS B, LACY PS, THOM SM, CRUICKSHANK K, STANTON A, COLLIER D, HUGHES AD, THURSTON H, O'ROURKE M: Differential impact of blood pressure-lowering drugs on central aortic pressure and clinical outcomes: principal results of the Conduit Artery Function Evaluation (CAFE) study. Circulation 113: 1213-1225, 2006.

YE S: Influence of matrix metalloproteinase genotype on cardiovascular disease susceptibility and outcome. Cardiovasc Res 69: 636-645, 2006.

YE S, ERIKSSON P, HAMSTEN A, KURKINEN M, HUMPHRIES SE, HENNEY AM: Progression of coronary atherosclerosis is associated with a common genetic variant of the human stromelysin-1 promoter which results in reduced gene expression. J Biol Chem 271: 13055-13060, 1996.

ZEE RY, BUBES V, SHRIVASTAVA S, RIDKER PM, GLYNN RJ: Genetic risk factors in recurrent venous thromboembolism: a multilocus, population-based, prospective approach. Clin Chim Acta 402: 189-192, 2009. 